\title{
Corporate financial structure and firm's decision to export
}

- Purpose: This study aims to analyse the decision to export in relation to financial issues, specifically the impact of corporate financial structure on a firm's export propensity (the likelihood of a firm becoming an exporter) by firm size.

- Design/methodology/approach: A multivariate probit model is applied to a sample of 8,019 Spanish manufacturing firms drawn from the Iberian Balance Sheet Analysis System (SABI). The analysis is performed separately for small, medium and large firms.

- Findings: The paper evidences, by firm size, a positive link between ownership concentration and export propensity, although for SMEs if shareholder concentration is very high it can be counterproductive. In addition, a high degree of liquidity influences the probability of entering export markets, while those firms that face high costs as result of their export activity may need to become indebted in order to secure the necessary financial resources. However, the strength of these latter effects differs in SMEs.

- Originality/value: This paper broadens our understanding of the relationship between firms' export propensity and their financial health and ownership concentration, an internal factor not previously considered in the international business literature despite its relevance for firm's decision to export. Our paper highlights that their influence is not uniform but affects firms of different sizes in different ways. This is of interest and value to scholars, investors and policy makers worldwide, since handling corporate financial structure and international strategies needs to be addressed in today's global business environment.

Keywords: Capital structure; financial constraints; ownership structure; export propensity; small and medium-size enterprises (SMEs).

JEL classification codes: G32, L25, F20. 


\section{Introduction}

International trade is traditionally considered one of the growth engines of a country; indeed, export activities boost the wealth not only of nations but also of individual firms. Accordingly, exporting has been widely studied in the literature of both economics and international business, featuring in-depth analyses of firm's export propensity ${ }^{\mathrm{i}}$ and stressing the heterogeneous characteristics of exporting and nonexporting firms (Bernard and Jensen, 1997; Roberts and Tybout, 1997). From this approach, several internal factors such as size, age and performance have been distinguished when accounting for firm's heterogeneity effects (Roberts and Tybout, 1997; Wagner, 2001; Mañez et al., 2008); either younger, smaller or less productive firms display a lower probability to export since they face bigger sunk costs (Roberts and Tybout, 1997) than their larger, older and more productive counterparts.

Taking this stream of research, the present paper conducts an in-depth look at firms' export propensity, based on an examination of firm-level data from the perspective of their manifest heterogeneity. Since traditional trade models based on a single source of firm heterogeneity fail to account for certain trade patterns (Serti et al., 2010), our analysis of export propensity includes not only the aforementioned explanatory factors, but also non-traditional ones related to corporate financial structure, such as financial constraints and ownership concentration.

Although the impact of financial constraints on firms' investment decisions has been a recurrent topic in the corporate finance literature, studies that examine financial issues in relation to the export decision are limited and generally restricted to static models (Caggese and Cuñat, 2011). Recent empirical studies of firms' heterogeneous productivity, conducted in line with Melitz (2003), stress that a firm's export propensity can be figured out as an investment decision, in which major costs have to be met. As 
such, financial constraints might supposed to be a key determinant of a firm's export behaviour (Chaney, 2005; Bellone et al., 2010; Manova, 2013; Muûls, 2015). In fact, in the presence of imperfect capital markets, less financially constrained firms - that is, those whose liquidity and leverage are in a healthy condition (Greenaway et al., 2007) enjoy easier access to foreign markets. While there is empirical evidence of its relevance for the SMEs, as they typically face greater problems obtaining financial resources (Ayob et al., 2015), comparative research between large and SMEs firms has remained underexplored. Thus, in compliance with the heterogeneity perspective we explicitly test the effect of financial constraints on export propensity by firm size.

Moreover, the effect of equity ownership on the specific decision to go international has not been deeply considered previously in the literature. Some effort has been devoted to examine the influence of shareholder identity on firm's international strategy, but always from the agency theory perspective (e.g. DosogluGuner, 2001; George et al., 2005; Fernández and Nieto, 2005; Filatotchev et al., 2007; Sciasci et al., 2012). As such, they seek to explain the influence of managementownership relationships on internationalization decisions, identifying the problems that might arise from differences in the incongruence of the principals and agents' attitudes and goals (Eisenhardt, 1989). In contrast, this paper differs from previous studies by applying the resource-based view (RBV) and directly tackling the influence of a firm's ownership concentration on its export decision, another issue that, to the best of our knowledge, has not been examined before.

Beginning to export is one of the risky and relevant firm's decision process that implies additional availability of financial resources to cope with the high presence of sunk costs (Roberts and Tybout, 1997), such as researching new foreign demand, establishing new marketing and distribution channels, adjusting product characteristics 
for meeting foreign tastes and fulfilling legislation of other countries (Girma et al., 2004). All these are risky actions because exporting investment decision payoff is really uncertain. Although there is evidence that export activities lead to a positive performance (i.e. Baldwin and $\mathrm{Gu}, 2003$ ), it only occurs in the long term. Thus, firms' engagement represents a key aspect because success is contingent on the firm's long term effort to increase participation in international markets. Then, it requires a full commitment over a sustained period by those shareholders controlling the firm (Dosoglu-Guner, 2001), that can be more easily achieved if there is a high percentage of equity concentration. In consequence, we posit that ownership concentration may play an important role in firm's export propensity.

Hence, in this article we address this gap in the literature by investigating two main research questions: i) Do a firm's financial constraints and its capital concentration impact its export propensity?; and, ii) Does this impact differ according to firm size?

This paper explores these questions in an effort at broadening our understanding of the relationship between export propensity and corporate financial structure. In doing so, it responds to recent calls in the literature to bring further ideas from corporate finance to the study of international trade and investment (Foley and Manova, 2015). Specifically, we examine the influence of liquidity, indebtedness and shareholders' concentration -alternative mechanisms for accessing financial resources- on the likelihood of a firm becoming an exporter. In addition, we draw inferences about the effect of firm size on any possible differences. To do this, this study employs a panel database containing details of 8,019 Spanish industrial manufacturing firms for the period 2002-2005, performing the analysis separately for small, medium and large firms. 
This paper makes two significant contributions. First, and foremost, we uncover the relevant effect of ownership concentration on a firm's export propensity; an internal factor that has not previously been examined in the literature. Specifically, our results point to the importance of considering differences in the percentage of capital concentration in relation to firm size: in the case of small firms, if the concentration is high (more than 50\%), the ownership concentration can be counterproductive. Second, we find evidence of the importance of liquidity for the probability of entering export markets, while those firms that face high costs as result of their export activity may need to become indebted in order to secure the necessary financial resources. However, we only have robust evidence of this positive effect for medium-sized firms. In addition, the nature of our sample, which allows for a longitudinal analysis by firm size, and the novelty of including traditional and non-traditional explanatory factors in a probit random effects model, provide a more comprehensive picture of the firm's decision to export and allows us to control for unobserved heterogeneity.

The paper is structured as follows. Section 2 reviews new internal factors for consideration and testing. Section 3 describes the database and the econometric strategy. Section 4 presents the empirical results. Finally, section 5 discusses the findings and the closing section 6 offers conclusions.

\section{Literature review and hypothesis development}

There appears to be a very clear connection between a firm's financial structure and its corporate strategic decisions (Porter, 1990). However, while there is considerable support for such an association, especially with respect to diversification strategy (Jensen and Meckling, 1976; Eisenhardt, 1989) and, more recently, innovation strategy (Chin et al., 2009; Lee, 2005), there is no conclusive evidence with regard to 
internationalisation strategy or export propensity.

Choosing to enter the export market is a major decision for any firm since it involves great long-term organisational and strategic repercussions. Direct export activity can be a lengthy, costly process with highly uncertain outcomes, owing to the need to develop suitable commercial infrastructure that can guarantee success. Moreover, export activity is linked to the strong presence of high sunk costs (Roberts and Tybout, 1997), such as looking for export market information (Okpara, 2009), researching new foreign demand or complying with the quality and safety legislation of other countries (Girma et al., 2004).

In this regard, the resource-based view (RBV) is a relevant theoretical framework given that it highlights the importance of strategic capabilities and resources for internationalisation (Peng, 2001). From this theoretical perspective, only firms with valuable resources generate competitive advantages and higher long-term performance (Barney, 1991). Indeed, financial funding is crucial for implementing an internationalisation strategy, especially as far as SMEs are concerned, because it provides the capital investment required to develop essential international capabilities and to face the high sunk costs associated with exporting.

Taking this approach, empirical studies based on firm-level trade data show a clear correlation between financial health and export propensity, with the former determining the financial resources available to a firm, which in turn condition its internationalisation strategy (Chaney, 2005; Greenaway et al., 2007; Bellone et al., 2010, Manova, 2013).

As such, financial constraints constitute a further source of heterogeneity and one that should be included to explain differences in export propensity across firms. Yet, empirical findings differ on the impact of financial constraints on exports. On the 
one hand, Chaney's (2005) model of international trade incorporating firm liquidity constraints shows that only firms with sufficient liquidity are able to afford the entry costs and access foreign markets. This finding is consistent with Bellone et al.'s (2010) study of a sample of French enterprises that shows that firms in better financial health are more likely to export and, less constrained firms are better able to start exporting. Furthermore, Muûls and Pisu (2009), working with a database of Belgian enterprises, report that even if financially constrained firms manage to access foreign markets, they tend to serve fewer destinations than those served by firms unaffected by credit constraints. On the other hand, Greenaway et al. (2007), drawing on a large dataset of UK manufacturing firms, explore the causal relationship between exporting and financial constraints, but report a reverse causality: Exporters enjoy better financial health but this is not a determinant of their participation in export markets. The authors claim that exporting boosts a firm's financial health, as participating in export markets for a long time tends to make firms more liquid and less leveraged. Campa and Shaver (2001) report results that point in the same direction. Using a panel of Spanish manufacturing firms in the 1990s, they conclude that the steadiness provided by foreign sales means a firm's liquidity constraints are less binding. Silva (2011) corroborates this result with data for Portuguese manufacturing enterprises, reporting a significant improvement in firms' financial health after entering export markets. Hence, based on the previous arguments we posit:

Hypothesis 1: The greater the firm's liquidity, the more likely it is to export.

In addition to the direction of the causal link, what also remains unclear is the relationship between the firm's leverage and its financial constraints. For example, 
Clark et al. (1996) argue that debt has a negative impact upon a firm's internationalisation since it may imply a greater risk of bankruptcy. However, high leverage may also suggest that the firm has had access to external financial resources in the past, so it is not currently suffering the effects of financial constraint. Exporters depend more on external financing than domestic firms since they face additional costs, greater transaction risks and higher working capital needs due to longer transport times (Manova, 2013). As such, we argue that the sign of the association between the level of leverage and export propensity depends on the ease with which a firm can access financial resources. Unlike large firms, SMEs have fewer internal resources they can resort for exporting (Requena-Silvente, 2005); therefore, if they opt to export they need to obtain external funding, even though they are more credit constrained (Antony et al., 2012) and this alternative considerably increases the related risk. Debt capital (including long-term debt) is riskier and more rigid than equity, as the firm has to repay loans and pay interest in line with strict schedules. Yet, for those firms with greater financial constraints, such as SMEs, a high leverage level may be the only way to implement export strategies that might offset their insufficient internal resources that permit undertake strategies with results on the long term. Exporters depend more on external financing than domestic producers because of additional costs related to trade. Therefore, early indebtedness decisions positively influences export propensity, especially in SMEs given their greater difficulties in accessing financial resources. In other words, the firm's leverage level may have influence on the chances to become an exporter according to the firm's easiness of accessing financial resources. Indeed, acquiring external financing for exporting is imperative but difficult for SMEs (Ayob et al., 2015), and for this reason smaller firms would display less export activities. Hence, it can also be argued that firms are heterogeneous with respect to finance (Antony et al., 
2012) and that when a firm opts for the internationalisation pathway its decision is based in part on its borrowing capacity and ability to access financial resources in the past (Graves and Thomas, 2008). Thus, we propose:

Hypothesis 2: The greater the access to external financial resources in the past, the more likely it is to export.

But liquidity and leverage are not the only essential components of a firm's financial health; equity is also a key factor in determining its corporate financial structure. More specifically, shareholders' equity and liabilities can be considered alternative mechanisms of corporate governance and an alternative source of financial funding for a firm. Therefore, they need to be taken into consideration in a heterogeneity approach to explaining a firm's export propensity.

RBV framework suggests that large-block investors may provide access to the resources required for developing international activities (Filatotchev et al., 2008). The decision to export involves risk because the investment pay-off is genuinely uncertain. Successful export activity improves performance (Baldwin and $\mathrm{Gu}, 2003$ ), but only in the long term. Therefore, success is contingent on a firm's long-term commitment to increasing its participation in international markets and this requires the full support of its main shareholders (Dosoglu-Guner, 2001). Given the critical importance of longterm commitment to internationalisation, i.e. 'patient' capital (Lukas et al., 2007) commonly associated with ownership concentration, plays a vital role in a firm's export propensity. Meyer, et al. (2006) describe 'commitment' as a force that binds the individual to a target and, consequently, to a course of action relevant to achieving that target. In this context, owners that have high equity share capital in a firm are more 
likely to show greater commitment to that firm (i.e. shared values, personal involvement, loyalty to the organisation, etc.). Therefore, the greater the concentration of the shareholding, the more tightly controlled a firm tends to be (Gaur, et al., 2015), and hence, the stronger the long-term commitment to internationalisation and the greater the amount of financial resources committed to the firm's export strategies. Nevertheless, if a firm's capital concentration is very high, even though internationalisation may be a source of value creation in the long term, the risk associated with it can be such that it might discourage the shareholders, particularly if the firm is small. According to George et al. (2005), SME owners in this situation tend to favour a more conservative approach to internationalisation, aiming to minimise the uncertainty regarding their income. They may need to share risk with other shareholders in the firm so as not to lower their wealth if, in the end, export activity does not succeed. Therefore, based on the above discussion we posit:

Hypothesis 3a: The higher the firm's ownership capital concentration, the greater the propensity to export of large firms.

Hypothesis 3b: The higher the firm's ownership capital concentration, the lesser the propensity to export of SMEs.

\section{Database and method}

\subsection{Data and sample characteristics}

This article analyses the country's export behaviour by means of the Iberian Balance Sheet Analysis System (SABI). This database, which has not previously been used for analysing the impact of firm heterogeneity on export propensity, is maintained by the 
Bureau Van Dijk and includes information about the company accounts, activities, ownership and management of almost one million Spanish firms. The object of this study is a sample comprising industrial manufacturing firms located in Spain with a turnover of more than 2 million euros and which provides complete information on their management and strategic variables (exports, ownership structure, financial ratios, diversification and FDI) for the period 2002-2005. The study includes additional information, specifically financial variables for the period 1998-2001, to provide details of the initial performance conditions for the estimation procedures. The resulting data comprise a panel of 8,019 Spanish manufacturing firms registered in the manufacturing sector using NCEA-93 Rev1: codes 15 to 36 (National Classification of Economic Activities provided by the Spanish National Institute of Statistics, INE). For reasons of sample representativeness, the paper uses sampling weights based on sector information taken from Fomento de la Producción (a database containing up-to-date information on the largest 30,000 Spanish companies in all of the country's industrial and service sectors).

Applying European turnover standards ${ }^{\mathrm{ii}}$, the sample is composed as follows: large firms (5\%), medium-sized firms (21.4\%) and small firms (73.6\%). In terms of their respective export propensity, $75.7 \%$ of large firms, $67.4 \%$ of medium-sized firms and only $47.7 \%$ of small firms were exporters.

Taking the sample as a whole, only $8.4 \%$ of Spanish manufacturing firms modified their export behaviour in the period 2002-2005. This percentage falls to just $6.9 \%$ if we take only small firms into consideration. This means that the probability of a firm commencing or curtailing its exporting activities from one year to the next is in general low and that for small firms the likelihood is even lower. In line with Bernard and Jensen $(1997 ; 2004)$ the evidence concerning sunk costs reinforces this point. 


\subsection{Econometric strategy and covariates}

The dependent variable, export propensity, is expressed as a dummy variable, taking a value of 1 if a firm exports during a particular year and 0 when exports sales are equal to zero. This measure is widely used in the empirical literature (Ottaviano and Volpe Martincus, 2011; George et al., 2005; Fernández and Nieto, 2005; Bernard and Jensen, 2004; Ayob et al, 2015).

To model a firm's decision to internationalise $\left(y_{i, t}\right)$, the present study uses a multivariate probit model where the equations to be estimated are as follows:

$$
y_{i, t}=\left\{\begin{array}{cc}
1 & X_{i, t}^{\prime} \delta+\alpha_{j 1}+\alpha_{j 2}+\mu_{t}+\varepsilon_{i} \\
0 & \text { otherwise }
\end{array}\right.
$$

where $i=1 \ldots N$ indicates firms; $j=1 \ldots k$ represents sectors, and $t=2002 \ldots 2005$ denotes the periods considered, assuming joint normality, independent distribution and an absence of serial correlation for $\varepsilon_{i}=\pi_{i}+u_{i, t}$ (where $\pi_{i}$ is an unobserved individual-specific effect that is time-invariant and $u_{i, t}$ is a time-varying idiosyncratic error term). Panel data have the advantage of allowing us to control for unobserved heterogeneity and to obtain stronger causal inference (Hsiao, 1985).

Among the characteristics considered $\left(X_{i, t-1}\right)$, the present approach includes several internal factors that affect the probability of a firm becoming an exporter. To capture a firm's ownership concentration, the corporate governance literature has relied on the percentage of share ownership held by the largest shareholders (e.g., Filatotchev et al., 2007; Gedajlovic and Shapiro, 1998; Thomsen and Pedersen, 2000). However, as we have a constraint imposed by the database, we include two dummy variables in our model so as to define share ownership intervals: the first, medium concentration level, takes a value of 1 if the firm has one or more shareholders with a percentage of share 
ownership between 25 and 50\% and 0 otherwise; and, a second, high concentration level, takes a value of 1 if the firm has one shareholder with an ownership percentage equal to or greater than $50 \%$ and 0 otherwise. Since, the base category corresponds to firms showing a low concentration level (i.e. less than $25 \%$ ), only variables of medium and high concentration level are made explicit in the econometric model.

To compute the firm's financial constraints, we use two variables: first, the liquidity ratio, i.e., current assets over current liabilities (Bellone et al., 2010; Silva, 2011); and, second, we measure the firm's level of leverage, using the variable debt measured as the annual percentage of total debt over total assets and lagged one period, as defined by Bernini et al., (2013); Fernández and Nieto (2005) and Becchetti and Trovato (2002).

As control variables, we introduce other firm's internal factors that traditionally account for export propensity. In accordance, firm's age, measured as the number of years a firm has been in existence (Sciascia et al., 2012); legal form, which takes a value of 0 for public limited companies and 1 for other legal forms; and firm size, expressed as a logarithm of the total amount of the firm's assets in thousands of euros lagged for one period (Gedajlovic and Shapiro, 1998) are included in the model.

Performance is captured in the model by the productivity ratio (addedvalue/number of employees) in log terms also lagged one period. Although no entry-exit import-export firms are observed in our longitudinal database, sunk costs are still observed. In other words, a firm's previous economic conditions have an impact on its export decisions because of the presence of fixed costs (Roberts and Tybout, 1997). Then, the parameters are biased. For this purpose, throughout the empirical analysis the study includes information regarding trade in lagged terms $\left(y_{i, t-1}\right)$; average past performance (operating revenues in logs) and volatility in past performance (EBITDA). 
These three indicators refer to the period 1998-2001. As the inclusion of the first variable means losing one year in the panel dimension, and as the results coincide, the present analysis prefers to include the other two covariates.

We include two additional variables to capture a firm's links to international networks. First, the presence of foreign shareholders in a firm's capital is captured by foreign firm. In line with Filatotchev et al. (2007), the variable is measured using a dummy variable that takes a value of 1 if the largest shareholder is foreign and 0 otherwise. Second, a firm's foreign direct investment is measured by the variable FDI, which is the number of foreign subsidiaries in which a firm has any percentage of ownership.

To capture diversification, in line with Requena-Silvente (2005), we introduce a dummy variable that takes a value of 1 if the firm operates in more than one industry and 0 otherwise. Moreover, we take into account three degrees of diversification based on information from NCEA codes; that is, low, medium and high diversification for firms that operate in at least two, three and four different sectors. Additionally, following Hitt et al. (1997), we add a dummy variable, type of diversification, that takes a value of 1 for unrelated diversification (firms operating in more than one business and declaring different first two digits in the NCEA codes) and 0 for related diversification (firms operating in related businesses and their NCEA codes have at least the same first two digits).

Finally, we include external factors to measure the effects of externality. Thus, we control for adjusted average share of exporters within the sector indicating spillovers within industries (Bernard and Jensen, 2004) and Spanish regions (Autonomous Communities - ACs) (Barrios et al., 2003; Mañez et al., 2008) expressed respectively as $\left(\alpha_{j 1}, \alpha_{j 2}\right)$ (corrected regional and sector spillovers as endogenous covariates, following 
Aitken et al., 1997). The latter allows us to include industrial fixed effects. The model also includes time fixed effects year dummies $\left(\mu_{t}\right)$ denoting macroeconomic environmental conditions.

\section{Empirical results}

Table 1 presents descriptive data on the export behaviour of Spanish manufacturing firms. It shows that firms that export are older; operate more frequently as public limited companies; present higher performance records; are more likely to belong to international networks but have almost the same intensity of diversification strategy as their non-exporter counterparts. In terms of their corporate financial structure, exporters are healthier, i.e., they present a higher degree of liquidity, lower debt ratios and higher levels of ownership concentration. Moreover, these differences between exporters and non-exporters are more marked in the case of small enterprises. For this reason, the present study has conducted separate regressions according to firm size.

Table 2 reports the final overall results. This table begins with the baseline estimation results (column 1) and then introduces the list of covariates either to test their influence separately or to check their robustness. Thus, column (2) shows the baseline results plus the list of covariates and columns ( 3 to 5 ) show the results when disaggregating the sample according to large, medium and small firms.

The results obtained corroborate the fact that the traditional factors determining export behaviour (covariates) are of undoubted validity in accounting for export propensity, especially in the case of small firms. Particularly noteworthy in this regard is the positive relationship between a firm's past experience (lagged export activity) as an exporter and its likelihood of exporting in the future, given that the coefficient of the 
lagged export variable is positive and statistically significant in all the estimations. Other findings worthy of mention refer to the variables measuring diversification. Interestingly, none of them presents a high level of significance, with the exception of that of high diversification in the subsample of small firms, which presents a highly significant negative correlation with export propensity.

In addition to these expected results, we find new evidence of the influence of corporate financial structure on a firm's export propensity. On the one hand, $\mathrm{H} 1$ and $\mathrm{H} 2$ predicted the influence of financial constraints (liquidity and leverage level) in accounting for export propensity. Nevertheless, our analysis yields mixed results as regards the factors analysed. For the whole sample, we can confirm the existence of a positive connection between liquidity and the probability of exporting (H1), albeit at a medium level of significance. This same result holds for small firms, which moreover count on fewer financial resources. In the case of debt (H2), we also find a positive and significant effect for all the firms regardless of their size but most significantly for medium-sized firms. However, the estimated coefficient for small firms is not statistically significant.

On the other hand, H3 predicted that the level of the firm's ownership concentration influences on the propensity to export. This relationship is corroborated in the case of firms with a medium concentration of ownership structure (between 25 and $50 \%$ ), while firms with a low level of concentration (less than $25 \%$ ) are unlikely to be exporters. Moreover, large firms with the highest concentration level (shareholders with a share greater than 50\%) present a greater probability of entering export markets. Consequently, this supports H3a since a medium level of firm's ownership concentration increases the propensity to export. However, it should be stressed that at the highest concentration of small firms, the coefficient is negative, indicating the 
opposite relationship. Hence, $\mathrm{H} 3 \mathrm{~b}$ is also supported since a higher concentration of ownership in SMEs (more than 50\% of capital in only one shareholder) has a negative impact reducing its probability of exporting.

[Insert Table 1 and 2 about here]

\section{Discussion}

This study applies a random-effects panel probit model to a sample of 8,019 Spanish manufacturing firms for the period 2002-2005 and shows that a firm's corporate financial structure is a relevant internal factor that has been often ignored in earlier empirical analyses. Indeed, our results demonstrate that a firm's ownership and financial structure should be taken into account when seeking to account for a firm's export propensity. Moreover, the impact of these internal factors is particularly important for SMEs and their probability of becoming exporters.

In this sense, the resource-based theory can at least partly predict the impact of differences in corporate financial structure on export behaviour. SMEs that present a medium level of ownership concentration (any owner with a share of between 25 and $50 \%$ ) are more likely to export than those that have no large-block shareholders (less than $25 \%$ which is the base category). Given the risks associated with adopting an export strategy, financing its activities requires a large-scale, long-term commitment to internationalisation ('patient' capital) on the part of a firm's shareholders. However, this study finds that for small firms a high ownership concentration (one owner with a share greater than 50\%) is counterproductive. This finding can be explained in terms of the greater perceived risk in undertaking export activities and the need to share the risks arising from internationalisation with more than one partner. The difference between the 
effect of high ownership concentration between small and large firms is due to the size and the availability of financial resources of their shareholders, which is stronger for the case of the latters. Regardless therefore of the sign of the relationship, the evidence clearly points to the existence of an influence of ownership concentration on a firm's export propensity. As such, our results provide additional support to the findings of Dosoglu-Guner (2001) and Filatotchev et al. (2008).

Our examination of the effect of financial constraints on a firm's export propensity reveals some evidence of the importance of liquidity and the degree of indebtedness. Indeed, our analysis shows that only firms with sufficient liquidity are able to access foreign markets. This result is in line with Chaney (2005) and Bellone et al. (2010), serving to confirm a causal relationship between export propensity and liquidity. We also find robust evidence for medium-sized firms of the positive effect of debt on exporting. This finding is consistent with the fact that smaller firms face greater obstacles accessing financial resources and so they may rely on external debt to fund their export activity. SMEs are more likely to be new entrants than they are to be continuous exporters. According to Greenaway et al. (2007), new entrants generally display poorer financial health, i.e., a high degree of leverage; however, since we do not have evidence here for small firms we can only partially confirm the connection between these two factors.

Moreover, the traditional factors underpinning export behaviour are also significant in accounting for a firm's export propensity in the Spanish manufacturing sector. Interestingly, these factors have a more intense impact in the case of SMEs: for instance, our results reveal a positive link between export propensity and a firm's internal characteristics (including age, size and initial performance and export conditions) that is stronger for smaller firms. This evidence is consistent with previous 
reports on firm heterogeneity (Roberts and Tybout, 1997; Wagner, 2001; Mañez et al., 2008) and export dynamics (Roberts and Tybout, 1997; Bernard and Jensen, 2004; Delgado et al., 2002).

Other findings worthy of mention include the fact that strategy diversification is found not to have a marked effect on exporting firms, except for high diversification which has a negative impact on small enterprises. Owing to the high sunk costs associated with export activity and the notable funding constraints faced by SMEs, past diversification decisions reduce the probability of becoming an exporter, partly confirming the findings of Mañez et al. (2008) and Aw and Batra (1998).

Moreover, this paper provides evidence of the positive impact on a firm's export propensity of its participating in international networks. This effect is also more significant for SMEs. Firms with sizeable foreign capital participation are more likely to be exporters than are domestically owned firms. This result is consistent with earlier studies in the literature (Kneller and Pisu, 2004; Mañez et al., 2008; Filatotchev et al., 2008, Manova et al., 2015). We also confirm that exporting and FDI are two complementary activities, forming part of a firm's overall whole international strategy. Thus, operating foreign subsidiaries does not reduce a firm's export activity, but rather it tends to boost it. In this regard, our results are in line with Bernard and Jensen (2004).

This study also confirms, for the case of Spain, the impact of regional and sector spillover effects (external factors) derived from geographical and industrial agglomerations on firms' export decisions, as identified by Bernard and Jensen (1997, 2004) and Barrios et al. (2003). Interestingly, the positive effects of these external factors (which serve to reduce the costs of exports and, hence, of becoming exporters) are significant only for SMEs and not for large firms. 


\section{Conclusions}

Corporate financial structure is a key issue that determines the internationalisation pathway of firms. However, to date, little effort has been devoted to exploring its influence on the export behaviour of firms and most importantly, few empirical studies have sought to systematically compare the international behaviour of small firms with that of medium and large companies with regard to financial issues.

Therefore, this article is a first attempt to bring financial insights to the study of not only differences between exporters and non-exporters but also how they vary across size groups. We find that some internal factors that favour export propensity in the case of large firms hint it in the case of small firms. This can be appreciated in the different effect of ownership concentration degree in relation to firm's size, and the lack of clear impact of indebtedness and liquidity on export behaviour of SMEs as compared to large firms. Overall, our paper highlights that their influence is not uniform but affects firms of different sizes in different ways.

These differential effects have relevant implications for designing export driving policies. Policy makers, aimed to enhance the development of a country through export promotion, should appraise the structure of national industrial fabric and tailor the policies in accordance. Particularly, in countries where small firms are predominant, government programs should encourage alliances between companies in order to share the perceived risk associated with internationalisation and counterbalance the negative effect of ownership concentration on export propensity. In contrast, in territories or industries where players are mainly large/medium companies, authorities should support mergers and acquisitions to stimulate processes of accumulation of capital in order to boost the positive effect of ownership concentration on firms' internationalisation. In addition, regardless the firm size, policies should also be 
directed at making loan programs readily available to local firms to fund export activities and guarantee sufficient liquidity to access foreign markets.

Nonetheless, these policy recommendations should be taken with care because this research is not deprived of limitations. First, an obvious limitation of this study concerns the fact that our database has no information regarding the length of time firms have spent in the export market. Future research would certainly seek to remedy this problem. Second, in the light of the results obtained a further in-depth examination of the effects of financial corporate structure on SMEs needs to be conducted. This would include not only selecting alternative measures for analysing the impact of the degree of concentration ownership, but also observing the influence of different shareholder types in seeking to account for export propensity, since the different stakes held and goals pursued could well influence their respective internationalisation strategies. Third, the analysis of more detailed variables regarding the effect of firms' financial health (e.g., short- and long-term debt; working capital; other solvency ratios) on export activity (e.g. export intensity; direct and indirect exports; foreign market destinations) by firm size, would doubtless enrich future studies.

\section{References}

Aitken, B., Hanson G.H., and Harrison, A.E. (1997), “Spillovers, foreign investment, and export behaviour", Journal of International Economics, Vol.43 No.1-2, pp.103-132.

Antony, J., Klarl, T., and Maußner, A. (2012), "Firm heterogeneity, credit constraints and endogenous growth", Journal of Economics, Vol.105 No.3, pp.199-224.

Ayob, A., Ramlee, S., Abdul-Rahman, A. (2015), "Financial Factors and Export Behavior of SMEs in an Emerging Economy”. Journal of International Entrepreneurship, Vol. 13 No.1, pp 49-66. 
Aw, B., and Batra, G. (1998), "Firm size and the Pattern of Diversification", International Journal of Industrial Organisation, Vol.16 No.3, pp.313-331.

Barney, J.B. (1991), "Firm resources and sustained competitive advantage", Journal of Management, Vol.17 No.1, pp.99-120.

Barrios, S., Görg, H., and Strobl, E. (2003), “Explaining firms’ export behaviour: R\&D, spillovers and the destination market", Oxford Bulletin of Economics and Statistics, Vol.65 No.4, pp.476-495.

Becchetti, L., and Trovato, G. (2002), "The Determinants of Growth for Small and Medium Sized Firms: The Role of the Availability of External Finance”, Small Business Economics, Vol.19 No.4, pp.291-306.

Baldwin, J., and Gu, B. (2003), "Export Market Dynamics and Plant-Level Productivity: Impact of Tariff Reductions and Exchange-Rate Cycles", Canadian Journal of Economics, Vol.36 No.3, pp.634-657.

Bellone, F., Musso, P., Nesta, L., and Schiavo, S. (2010), "Financial Constraints and Firm Export Behaviour", The World Economy, Vol.33, No.3, pp.347-373.

Bernard, A., and Jensen, B. (1997), Why some firms export: experience, entry costs, spillovers and subsidies. Mimeo, Yale USA.

Bernard, A., and Jensen, B. (2004), "Why some firms export", The Review of Economics and Statistics, Vol.86 No.2, pp.561-569.

Bernini, M., Guillou, S., and Bellone, F. (2013), "Firms leverage and export quality: evidence from France", Documents de Travail de l'OFCE 2013-13. Observatoire Francais des Conjonctures Economiques (OFCE).

Caggese, A., and Cuñat, V. (2001), "Financing constraints, firm dynamics, export decisions, and aggregate productivity”, working paper, London School of 
Economics and Political Science, version available at:

http://eprints.lse.ac.uk/43160/

Campa, J., and Shaver, J.M. (2001), Exporting and capital investment: On the strategic behavior of exporters. Mimeo, New York University.

Chaney, T. (2005), Liquidity Constrained Exporters. Mimeo, University of Chicago.

Chin, C.L., Chen, Y.L., Kleinman, G., and Lee, P. (2009), “Corporate ownership structure and innovation: evidence from Taiwan's Electronics Industry", Journal of Accounting, Auditing \& Finance, Vol.24 No.1, pp.145-175.

Clark, T., Rajaratnam, D., and Smith, T. (1996), "Towards a theory of international services: marketing intangibles in a world of nations", Journal of International Marketing, Vol.4 No.2, pp.9-28.

Delgado, M., Fariñas, J., and Ruano, S. (2002), "Firm productivity and export markets: a non-parametric approach", Journal of International Economics, Vol.57 No.2, pp.397-422.

Dosoglu-Guner, B. (2001), "Can organizational behavior explain the export intention of firms? The effects of organizational culture and ownership type", International Business Review, Vol.10 No.1, pp.71-89.

Eisenhardt, K.M. (1989), “Agency theory: An assessment and review”, Academy of Management Review, Vol.14 No.1, pp.57-74.

Fernández, Z., and Nieto, M.J. (2005), "Internationalization strategy of small and medium-sized family business: Some influential factors", Family Business Review, Vol.18 No.1, pp.77-89.

Filatotchev, I., Isachenkova, N., and Mickiewicz, T. (2007), “Corporate governance, managers' independence, exporting, and performance of firms in Transition Economies", Emerging Markets and Trade, Vol.43 No.5, pp.62-77. 
Filatotchev, I., Stephan, J., and Jindra, B. (2008), “Ownership structure, strategic controls and exporting of foreign-invested firms in transition economies", Journal of International Business Studies, Vol.39 No.7, pp.1133-1148.

Foley, C.F., and Manova, K. (2015), “International trade, multinational activity, and corporate finance", Annual Review of Economics, Vol.7 No.1, pp. 119-146.

Gaur, S.S., Bathula, H., Singh, D.(2015), “Ownership concentration, board characteristics and firm performance: A contingency framework", Management Decision, Vol. 53 No.5, pp.911-931.

Gedajlovic, E.R., and Shapiro, D.M. (1998), "Management and ownership effects: evidence from five countries", Strategic Management Journal, Vol.19 No.6, pp.533-553.

George, G., Wiklund, J., and Zahra, S. (2005), "Ownership and the internationalization of small firms", Journal of Management, Vol.31 No.2, pp.210-233.

Girma, S., Greenaway, D., and Kneller, R. (2004), "Does exporting increase productivity? A microeconometric Analysis of Matched Firms”, Review of International Economics, Vol.12 No.5, pp.855-866.

Graves, C.H., and Thomas, J. (2008), "Determinants of the internationalization pathways of family firms: an examination of family influence". Family Business Review, Vol.21 No.2, pp.151-162.

Greenaway, D., Guariglia, A., and Kneller, R. (2007), "Financial factors and exporting decisions", Journal of International Economics, Vol.73 No.2, pp.377-395.

Hitt, M.A., Hoskisson, R.E., and Kim, H. (1997), "International diversification: Effects on innovation and firm performance in product-diversified firms", Academy of Management Journal, Vol.40 No.4, pp.767-798. 
Hsiao, C. (1985), "Benefits and limitations of panel data", Econometric Review, Vol.4 No.1, pp.121-74.

Jensen, M.C., and Meckling, W.F. (1976), “Theory of the firm: Managerial behavior, agency costs and ownership structure", Journal of Financial Economics, Vol.3 No.4, pp.305-360.

Kneller, R, and Pisu, M. (2004), "Export-oriented FDI in the UK". Oxford Review of Economic Policy, Vol.20 No.3, pp.424-439.

Lee, P.M. (2005), “A comparison of ownership structures and innovations of US and Japanese firms", Managerial and decision economics, Vol.26 No.1, pp.39-50.

Lukas, B.A., Gregory, J., and Hill, P. (2007), "Export planning orientation and its antecedents: evidence from exporting IT products", Journal of Business Research, Vol.60 No.12, pp.1282-1289.

Melitz, M.J. (2003), “The impact of trade on intra-industry reallocations and aggregate industry productivity”, Econometrica, Vol.71 No.6, pp.1675-1725.

Mañez, J.A., Rochina-Barrachina, M.E., and Sanchís, J.A. (2008), “Sunk Costs Hysteresis in Spanish Manufacturing Exports", Review of World Economics, Vol.144 No.2, pp.272-294.

Manova, K. (2013), "Credit Constraints, Heterogeneous firms, and International Trade”, Review of Economic Studies, Vol.80 No.2, pp.711-744.

Manova, K., Wei, S.J., and Zhang, Z. (2015), "Firm exports and multinational activity under credit constraints", Review of Economics and Statistics, Vol.97 No.3, pp.574-588.

Meyer, J.P., Becker, T.E., and Van Dick, R. (2006), "Social identities and commitments at work: toward an integrative model", Journal of Organizational Behaviour, Vol.27 No.5, pp.665-683. 
Muûls, M., and Pisu, M. (2009), "Imports and Exports at the Level of the Firm: Evidence from Belgium”, World Economy, Vol.32 No.5, pp.692-734.

Muûls, M. (2015), "Exporters, importers and credit constraints", Journal of International Economics, Vol.95 No.2, pp. 333-343.

Okpara, J.O. (2009), "Strategic choices, export orientation and export performance of SMEs in Nigeria", Management Decision, Vol.47 No.8, pp.1281-1299.

Ottaviano, G., and Volpe Martincus, C. (2011), "SMEs in Argentina: Who are the exporters?", Small Business Economics Journal, Vol.37 No.3, pp.341-361.

Peng, M. (2001), “The resource-based view and international business", Journal of management, Vol.27 No.6, pp.803-829.

Porter, M. (1990), The competitive advantage of nations, Free Press, New York.

Requena-Silvente, F. (2005), "The decision to enter and exit foreign markets: evidence from U.K. SMEs”, Small Business Economics, Vol.25 No.3, pp.237-253.

Roberts, M., and Tybout, J. (1997), “The decision to export in Colombia: An empirical model of entry with sunk costs", American Economic Review, Vol.87 No.4, pp.545-564.

Sciascia, S., Mazzola, P., Astrachan, J.H., and Pieper, T.M. (2012), "The role of family ownership in international entrepreneurship: exploring nonlinear effects", Small Business Economics, Vol.38 No.1, pp.15-31.

Serti, F., Tomasi, C., and Zanfei, A. (2010), "Who trades with whom? Exploring the links between firms' international activites, skills and wages", Review of International Economics, Vol.18 No.5, pp.951-971.

Silva, A. (2011), "Financial constraints and exports: evidence form Portuguese manufacturing firms", International Journal of Economic Sciences and Applied Research, Vol.4 No.3, pp.7-19. 
Thomsen, S., and Pedersen, T. (2000), “Ownership structure and economic performance in the largest European companies". Strategic Management Journal, Vol.21 No.6, pp.689-705.

Wagner, J. (2001), A note on the firm size-export relationship. Small Business Economics, Vol.17 No.4, pp.229-237. 
Table 1 Descriptive data of Spanish manufacturing firms included in the regression results in 2005

\begin{tabular}{|c|c|c|c|c|c|c|c|}
\hline & Overall sample & Trade $=0$ & Trade $=1$ & $\begin{array}{c}\text { Large \& } \\
\text { Trade = } 1\end{array}$ & $\begin{array}{c}\text { Medium \& } \\
\text { Trade }=1\end{array}$ & $\begin{array}{c}\text { Small \& } \\
\text { Trade }=0\end{array}$ & $\begin{array}{c}\text { Small \& } \\
\text { Trade }=1\end{array}$ \\
\hline \multicolumn{8}{|l|}{ Firm characteristics } \\
\hline Firm's age & $22.99(12.58)$ & $19.47(11.25)$ & $24.14(13.24)$ & $30.23(19.85)$ & $26.31(14.89)$ & $18.67(10.03)$ & $22.65(11.25)$ \\
\hline Not operating as public limited company & $0.42(0.49)$ & $0.50(0.50)$ & $0.34(0.48)$ & $0.16(0.36)$ & $0.24(0.42)$ & $0.55(0.50)$ & $0.41(0.49)$ \\
\hline EBITDA in log terms & $6.19(1.33)$ & $5.99(1.23)$ & $6.36(1.39)$ & $9.09(1.26)$ & $7.27(0.91)$ & $5.65(0.94)$ & $5.71(0.93)$ \\
\hline Firm size as total assets turnover in log terms & $8.58(1.12)$ & $8.34(1.00)$ & $8.78(1.17)$ & $11.41(1.03)$ & $9.67(0.60)$ & $8.01(0.64)$ & $8.16(0.63)$ \\
\hline Productivity ratio in log terms & $5.10(0.75)$ & $5.08(0.79)$ & $5.11(0.72)$ & $5.78(0.80)$ & $5.38(0.65)$ & $5.01(0.73)$ & $4.94(0.66)$ \\
\hline \multicolumn{8}{|l|}{ Foreign Direct Investment } \\
\hline Foreign firm & $0.05(0.23)$ & $0.04(0.19)$ & $0.07(0.25)$ & $0.27(0.44)$ & $0.13(0.34)$ & $0.02(0.12)$ & $0.02(0.14)$ \\
\hline Number of foreign subsidiaries & $0.17(0.78)$ & $0.06(0.45)$ & $0.27(0.97)$ & $1.46(2.23)$ & $0.47(1.17)$ & $0.02(0.14)$ & $0.07(0.39)$ \\
\hline \multicolumn{8}{|l|}{ Diversification Strategy } \\
\hline Low diversification level & $0.48(0.50)$ & $0.48(0.50)$ & $0.47(0.50)$ & $0.38(0.49)$ & $0.44(0.50)$ & $0.49(0.50)$ & $0.49(0.50)$ \\
\hline Medium diversification level & $0.13(0.34)$ & $0.14(0.35)$ & $0.13(0.34)$ & $0.09(0.29)$ & $0.12(0.32)$ & $0.14(0.35)$ & $0.14(0.34)$ \\
\hline High diversification level & $0.02(0.14)$ & $0.02(0.15)$ & $0.02(0.13)$ & $0.02(0.14)$ & $0.02(0.15)$ & $0.02(0.15)$ & $0.02(0.12)$ \\
\hline Type of diversification & $0.14(0.34)$ & $0.14(0.34)$ & $0.14(0.34)$ & $0.11(0.31)$ & $0.13(0.34)$ & $0.14(0.35)$ & $0.14(0.35)$ \\
\hline \multicolumn{8}{|l|}{ Capital Structure } \\
\hline Medium concentration level & $0.07(0.26)$ & $0.06(0.23)$ & $0.09(0.28)$ & $0.10(0.30)$ & $0.12(0.33)$ & $0.05(0.22)$ & $0.07(0.25)$ \\
\hline High concentration level & $0.03(0.16)$ & $0.02(0.14)$ & $0.03(0.18)$ & $0.07(0.26)$ & $0.06(0.23)$ & $0.01(0.12)$ & $0.02(0.14)$ \\
\hline Debt & $58.78(21.82)$ & $60.32(22.33)$ & $57.45(21.27)$ & $59.52(20.44)$ & $57.19(21.09)$ & $60.85(22.10)$ & $57.40(21.40)$ \\
\hline Liquidity & $1.68(5.57)$ & $1.62(2.54)$ & $1.85(7.14)$ & $1.48(0.98)$ & $1.71(1.59)$ & $1.63(2.68)$ & $1.93(8.52)$ \\
\hline Sample size & 8,019 & 3,689 & 4,330 & 292 & 1,157 & 3,020 & 2,881 \\
\hline
\end{tabular}

Note: average values and standard deviations in brackets. 
Table 2 ML results for Export activity: firm's size dissimilar effects

\begin{tabular}{|c|c|c|c|c|c|}
\hline & Baseline & $\begin{array}{l}\text { Baseline \& } \\
\text { Covariates }\end{array}$ & Large & Medium & Small \\
\hline Lagged export activity & $2.963(76.88)^{* * *}$ & $2.900(67.27)^{* * *}$ & $2.275(9.47)^{* * *}$ & $2.456(26.00)^{* * *}$ & $3.124(65.44)^{* * *}$ \\
\hline \multicolumn{6}{|l|}{ Externalities } \\
\hline Adjusted regional spillovers & & $0.719(4.99) * * *$ & $0.586(1.12)$ & $0.745(2.58) * *$ & $0.693(3.95)^{* * *}$ \\
\hline Adjusted sectorial spillovers & & $0.696(4.78) * * *$ & $0.922(1.51)$ & $0.695(2.39) * *$ & $0.683(3.88) * * *$ \\
\hline \multicolumn{6}{|l|}{ Firm characteristics } \\
\hline Firm's age in log terms & & $-0.020(-0.80)$ & $0.309(4.44)^{* * *}$ & $0.062(1.32)$ & $0.423(20.00)^{* * *}$ \\
\hline Not operating as public limited company & & $0.002(0.06)$ & $-0.236(-1.80)^{*}$ & $0.048(0.81)$ & $-0.104(-5.07)^{* * *}$ \\
\hline Lagged productivity ratio in log terms & & $0.324(3.73)^{* * *}$ & $0.447(0.90)$ & $0.241(0.85)$ & $0.192(1.80)^{*}$ \\
\hline Lagged squared productivity ratio in log terms & & $-0.034(-4.33)^{* * *}$ & $-0.056(-1.46)$ & $-0.028(-1.13)$ & $-0.019(-1.97)^{* *}$ \\
\hline Firm size as lagged total assets in log terms & & $0.533(3.93)^{* * *}$ & $1.529(1.75)^{*}$ & $0.767(1.14)$ & $0.649(3.05)^{* * *}$ \\
\hline Squared lagged total assets in log terms & & $-0.028(-3.52)^{* * *}$ & $-0.073(-1.88)^{*}$ & $-0.035(-1.00)$ & $-0.031(-2.34)^{* *}$ \\
\hline \multicolumn{6}{|l|}{ Initial conditions } \\
\hline Average operating revenue initial conditions & & $0.018(0.88)$ & $-0.082(-1.32)$ & $-0.034(-0.94)$ & $0.049(1.67)^{*}$ \\
\hline Volatility EBITDA initial conditions & & $0.000(1.31)$ & $0.000(2.67)^{* * *}$ & $0.000(2.74)^{* * *}$ & $0.000(-0.07)$ \\
\hline \multicolumn{6}{|l|}{ International networks } \\
\hline Foreign firm & & $0.412(9.15)^{* * *}$ & $0.048(0.44)$ & $0.423(6.56)^{* * *}$ & $0.527(6.48)^{* * *}$ \\
\hline Number of foreign subsidiaries & & $0.226(12.12)^{* * *}$ & $0.077(2.54)^{* *}$ & $0.262(9.13)^{* * *}$ & $0.337(7.92) * * *$ \\
\hline \multicolumn{6}{|l|}{ Diversification Strategy } \\
\hline Low diversification level & & $0.016(0.54)$ & $-0.169(-1.39)$ & $-0.020(-0.33)$ & $0.037(1.61)$ \\
\hline Medium diversification level & & $-0.090(-1.88)^{*}$ & $-0.375(-1.83)^{*}$ & $-0.072(-0.71)$ & $0.009(0.25)$ \\
\hline High diversification level & & $0.218(1.85)^{*}$ & $1.157(1.80)^{*}$ & $0.375(1.35)$ & $-0.260(-2.72)^{* * *}$ \\
\hline Type of diversification & & $0.026(0.64)$ & $0.251(1.27)$ & $0.054(0.65)$ & $-0.028(-0.88)$ \\
\hline \multicolumn{6}{|l|}{ Capital Structure } \\
\hline Medium concentration level & $0.162(4.91)^{* * *}$ & $0.083(2.37)^{* *}$ & $-0.366(-1.19)$ & $0.162(1.82)^{*}$ & $0.163(3.89)^{* * *}$ \\
\hline High concentration level & $0.111(2.01)^{* *}$ & $-0.155(-2.61)^{* * *}$ & $1.225(3.13)^{* * *}$ & $-0.123(-0.97)$ & $-0.182(-2.25)^{* *}$ \\
\hline Lagged Indebtedness & $0.056(2.20)^{* *}$ & $0.078(2.88)^{* * *}$ & $0.245(1.77)^{*}$ & $0.242(3.85)^{* * *}$ & $0.050(1.50)$ \\
\hline Liquidity & $0.005(2.18)^{* *}$ & $0.005(2.11)^{* *}$ & $0.109(1.74)^{*}$ & $0.023(1.44)$ & $0.005(2.26)^{* *}$ \\
\hline Time dummies & YES & YES & YES & YES & YES \\
\hline Sample size & 23,662 & 22,915 & 798 & 4,675 & 17,442 \\
\hline Wald $\chi^{2}$ & $6,235.50(0.00)$ & $10,881.25(0.00)$ & $253.20(0.00)$ & $1,918.72(0.00)$ & $8,271.49(0.00)$ \\
\hline
\end{tabular}


${ }^{i}$ Export propensity refers to the likelihood of a firm becoming an exporter. This differs from export intensity, which is the percentage of a firm's sales that are sold on foreign markets.

ii Specifically, large firms have over 50 million euros in operating revenues; medium firms between 10 and 50 million euros; and small firms up to 10 million euros. 